\title{
Increased concentration of plasminogen activator inhibitor-1 and fibrinogen in individuals with metabolic syndrome
}

\author{
IVÁN G. PALOMO ${ }^{1}$, CÉSAR L. GUTIÉRREZ ${ }^{1}$, MARCELO L. ALARCÓN ${ }^{1}$, JULIO C. JARAMILLO ${ }^{1}$, \\ FABIÁN M. SEGOVIA ${ }^{1}$, ELBA M. LEIVA ${ }^{1}$, VERÓNICA E. MUJICA ${ }^{1}$, GLORIA N. ICAZA ${ }^{2}$, \\ NORA S. DÍAZ ${ }^{2}$ and RODRIGO MOORE-CARRASCO ${ }^{1}$ \\ ${ }^{1}$ Department of Clinical Biochemistry and Immunohematology, School of Health Sciences, \\ ${ }^{2}$ Institute of Mathematics and Physics, Universidad de Talca, Talca, Chile \\ Received October 27, 2008; Accepted December 16, 2008 \\ DOI: 10.3892/mmr_00000092
}

\begin{abstract}
Metabolic syndrome (MS) is closely linked to a generalized metabolic disorder referred to as insulin resistance. Disturbances in the hemostasis and fibrinolytic systems are a feature of MS. The aim of this study was to determine the concentration levels of fibrinogen and plasminogen activator inhibitor-1 (PAI-1) in a group of patients with MS with respect to a non-MS group, and to evaluate their possible relation with other risk factors in MS. The study was carried out in a total of 186 male and female non-smoking individuals aged 45-64 years, 93 with MS (ATP III criteria) and 93 without MS. Plasmatic levels of PAI-1 were measured by ELISA, and those of fibrinogen by the Claus method. The plasmatic levels of PAI-1 (men $49.2 \pm 19.8$ vs. $35.0 \pm 12.2 \mathrm{ng} / \mathrm{ml}$ and women $42.0 \pm 19.7$ vs. $31.6 \pm 14.6 \mathrm{ng} / \mathrm{ml} ; \mathrm{p}=0.0026)$ and fibrinogen $(274.0 \pm 82.1$ vs. $232.7 \pm 66.6 \mathrm{ng} / \mathrm{ml} ; \mathrm{p}=0.0002)$ were $\mathrm{sig}$ nificantly higher in the MS group than in the non-MS group. PAI-1 was significantly associated with diastolic blood pressure, triglycerides and waist circumference. Fibrinogen was negatively associated with HDL-c. High plasmatic levels of PAI-1 and fibrinogen contribute to the cardiovascular risk that characterizes individuals with MS.
\end{abstract}

\section{Introduction}

The term metabolic syndrome (MS) describes a collection of lipid and non-lipid risk factors for cardiovascular disease (CVD), and is closely related to a generalized metabolic disorder referred to as insulin resistance (1-3). The National Cholesterol Education Program/Adult Treatment Panel (ATP) III has proposed a definition of MS (4). According to these

Correspondence to: Dr Iván G. Palomo, Department of Clinical Biochemistry and Immunohematology, School of Health Sciences, Universidad de Talca, P.O. Box: 747, Talca, Chile

E-mail: ipalomo@utalca.cl

Key words: metabolic syndrome, plasminogen activator inhibitor-1, fibrinogen criteria, $23.7 \%$ of North Americans 20 years of age or older presented with MS in 2001 (5). In Chile, the prevalence in adults was $23.0 \%$ in 2003 (6). We found that the prevalence of MS in adults in our city (Talca), according to the ATP III and International Diabetes Federation criteria after adjustment for age and gender, was 29.5 and $36.4 \%$, respectively (7).

Fatty tissue is considered to be an endocrine tissue that secretes several adipokines, as well as plasminogen activator inhibitor-1 (PAI-1). These molecules regulate the metabolic aspects of carbohydrates and lipids, the endothelium, inflammatory processes, hemostasis, and other processes $(8,9)$.

Various studies have confirmed that MS is a predictor of an elevated risk of coronary heart disease (10-13). Disturbances in the thrombotic and fibrinolytic systems have been described in MS. Several studies have established that risk factors for CVD include high levels of PAI-1 and fibrinogen (14-17). In order to explore this relationship, we measured the concentrations of PAI-1 and fibrinogen in Chilean subjects with and without MS.

\section{Patients and methods}

Patients. The study subjects were randomly selected from individuals enrolled in the 'Cardiovascular Profile of Adults of Talca, 2005' project, the intial results of which were recently published (18). A total of 186 non-smoking individuals 45-64 years of age were selected from two groups: a group of patients with MS (45 men and 48 women) and a group without MS (38 men and 55 women). All subjects included in this study were white Hispanics.

ATP III criteria (4) were used for the diagnosis of MS, including the presence of three or more of the following factors: waist circumference $(>102 \mathrm{~cm}$ for men and $>88 \mathrm{~cm}$ for women), high blood pressure $(\geq 130 / 85 \mathrm{mmHg}$ or arterial hypertension in treatment), hyperglycemia $(>100 \mathrm{mg} / \mathrm{dl}$ or diabetes in treatment; modified according to ADA 2005) (19), hypertriglyceridemia (>150 mg/dl) and low HDL-c ( $<40 \mathrm{mg} / \mathrm{dl}$ for men and $<50$ for women).

Anthropometric and arterial pressure measurements, as well as blood extractions, were made at the School of Health Sciences, Universidad de Talca, Chile (described by health professionals according to national ministerial and international norms) $(20,21)$. 
Table I. Characteristics of the study population by gender.

\begin{tabular}{|c|c|c|c|c|c|c|}
\hline & \multicolumn{2}{|c|}{ Metabolic syndrome group $(n=93)$} & \multicolumn{2}{|c|}{ Non-metabolic syndrome group $(n=93)$} & \multicolumn{2}{|c|}{ p-value } \\
\hline & Men $(n=44)$ & Women $(n=49)$ & Men $(n=38)$ & Women $(\mathrm{n}=55)$ & Men & Women \\
\hline Age (years) & $54.6 \pm 5.7$ & $54.1 \pm 5.7$ & $54.2 \pm 5.0$ & $52.9 \pm 6.0$ & 0.7211 & 0.2901 \\
\hline Glycemia (mg/dl) & $124.8 \pm 44.8$ & $110.1 \pm 41.8$ & $96.9 \pm 32.3$ & $91.5 \pm 24.0$ & 0.0016 & 0.0076 \\
\hline Total cholesterol (mg/dl) & $207.0 \pm 49.4$ & $206.4 \pm 38.1$ & $192.2 \pm 34.5$ & $204.6 \pm 32.0$ & 0.1142 & 0.7865 \\
\hline LDL-c (mg/dl) & $117.7 \pm 28.3$ & $123.0 \pm 31.3$ & $112.1 \pm 31.3$ & $116.7 \pm 28.0$ & 0.4120 & 0.2856 \\
\hline HDL-c (mg/dl) & $41.8 \pm 12.0$ & $48.0 \pm 11.9$ & $49.9 \pm 13.1$ & $64.7 \pm 15.2$ & 0.0048 & $<0.0001$ \\
\hline Triglycerides (mg/dl) & $262.0 \pm 197.5$ & $176.2 \pm 64.1$ & $161.3 \pm 99.1$ & $114.3 \pm 40.8$ & 0.0041 & $<0.0001$ \\
\hline Waist circumference $(\mathrm{cm})$ & $105.0 \pm 10.1$ & $98.7 \pm 10.1$ & $93.5 \pm 8.7$ & $86.3 \pm 11.3$ & $<0.0001$ & $<0.0001$ \\
\hline Systolic pressure (mmHg) & $143.5 \pm 15.3$ & $138.5 \pm 20.0$ & $133.0 \pm 17.5$ & $127.9 \pm 19.6$ & 0.0046 & 0.0077 \\
\hline Diastolic pressure (mmHg) & $88.2 \pm 10.7$ & $83.7 \pm 9.7$ & $82.8 \pm 11.7$ & $76.1 \pm 10.0$ & 0.0322 & 0.0002 \\
\hline BMI $\left(\mathrm{kg} / \mathrm{m}^{2}\right)$ & $30.7 \pm 3.9$ & $33.5 \pm 6.7$ & $27.1 \pm 2.9$ & $27.0 \pm 5.0$ & $<0.0001$ & $<0.0001$ \\
\hline
\end{tabular}

Data are expressed as the mean \pm standard deviation. HDL-c, high-density lipoprotein cholesterol; LDL-c, low-density lipoprotein cholesterol; BMI, body mass index.

Table II. Percentage of subjects meeting ATP III criteria in the metabolic syndrome and non-metabolic syndrome groups.

\begin{tabular}{|c|c|c|c|c|c|c|}
\hline & \multicolumn{2}{|c|}{ Metabolic syndrome group $(n=93)$} & \multicolumn{2}{|c|}{ Non-metabolic syndrome group $(n=93)$} & \multicolumn{2}{|c|}{$\mathrm{p}$-value } \\
\hline & $\operatorname{Men}(n=44)$ & Women $(n=49)$ & $\operatorname{Men}(n=38)$ & Women $(n=55)$ & Men & Women \\
\hline $\begin{array}{l}\text { Hypertension } \\
(\geq 130 / 85 \mathrm{mmHg})\end{array}$ & 90.9 & 83.7 & 55.3 & 47.3 & $<0.001$ & $<0.001$ \\
\hline $\begin{array}{l}\text { Low HDL-c } \\
(\mathrm{men}<40 \mathrm{mg} / \mathrm{dl}, \\
\text { women }<50 \mathrm{mg} / \mathrm{dl})\end{array}$ & 56.8 & 71.4 & 15.8 & 9.1 & $<0.001$ & $<0.0001$ \\
\hline $\begin{array}{l}\text { High triglyceride } \\
(>150 \mathrm{mg} / \mathrm{dl})\end{array}$ & 72.7 & 63.3 & 36.8 & 9.1 & 0.0020 & $<0.0001$ \\
\hline $\begin{array}{l}\text { High glycemia } \\
(\geq 100 \mathrm{mg} / \mathrm{ml})\end{array}$ & 72.7 & 51.0 & 21.1 & 9.1 & $<0.0001$ & $<0.0001$ \\
\hline $\begin{array}{l}\text { High waist circumference } \\
(\text { men }>102 \mathrm{~cm}, \\
\text { women }>88 \mathrm{~cm})\end{array}$ & 54.6 & 87.8 & 7.9 & 34.6 & $<0.0001$ & $<0.0001$ \\
\hline
\end{tabular}

Data are expressed as a percentage. HDL-c, high-density lipoprotein cholesterol.

Laboratory assays. To determine fibrinogen plasmatic levels, the Claus method (DG-FIB Kit Grifols) was used with a Clot1-coagulometer (RAL, Barcelona, Spain). For quantification of PAI-1, the ELISA Kit Zymutest (Hyphen Biomed) was used. The optical densities (OD) were read at $450 \mathrm{~nm}$ by a StatFax-2600 microplate reader (Awareness Technology Inc., Palm City, Florida).

Statistical analysis. Covariance analysis was performed to evaluate the plasma levels of PAI-1 and fibrinogen in the MS and non-MS groups, controlled by age and gender. In order to identify which MS diagnostic criteria individually affect plasma levels of PAI-1 and fibrinogen, a multivariate regression analysis was performed with adjustment for age and gender. Linear regression analysis was carried out to evaluate the effect of the number of MS components in plasma levels of PAI-1 and fibrinogen controlled by age and gender. Diagnostic regression measures were used to evaluate normality and homocedasticity assumptions. SAS 9.1.3 and SPSS 14.0 were used for statistical analysis. A 5\% level of significance was used.

\section{Results}

The characteristics of the population studied are presented in Table I. The percentages of subjects in the MS and non-MS groups meeting MS criteria according to the ATP III definition are presented in Table II. 


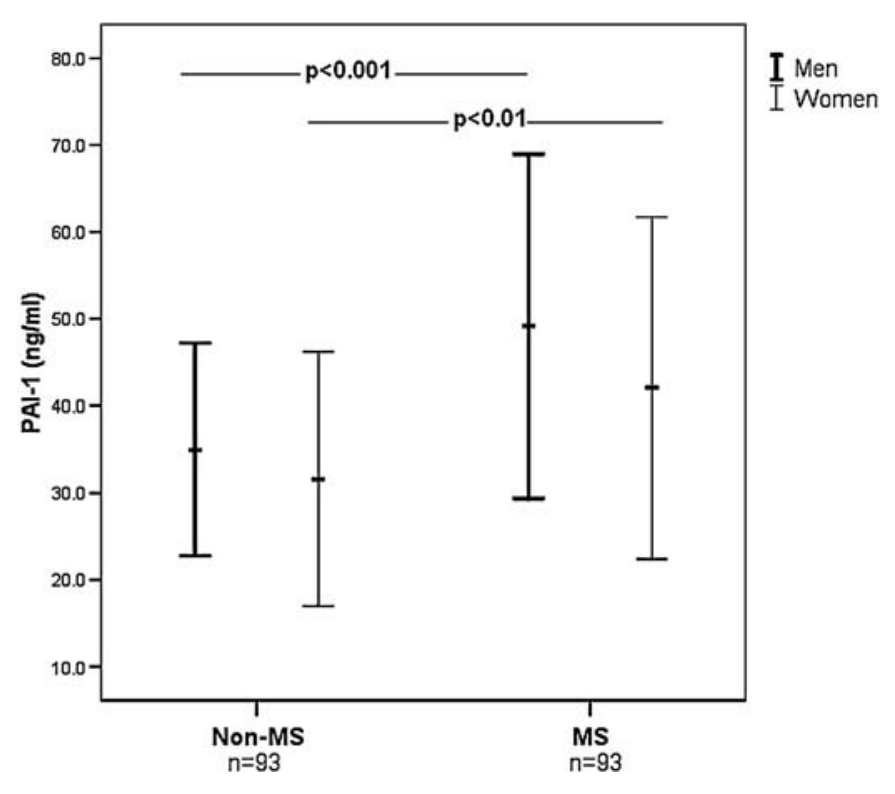

Figure 1. Mean and standard deviations for plasma concentrations of plasminogen activator inhibitor-1 (PAI-1) in the metabolic syndrome (MS) and control (non-MS) groups.

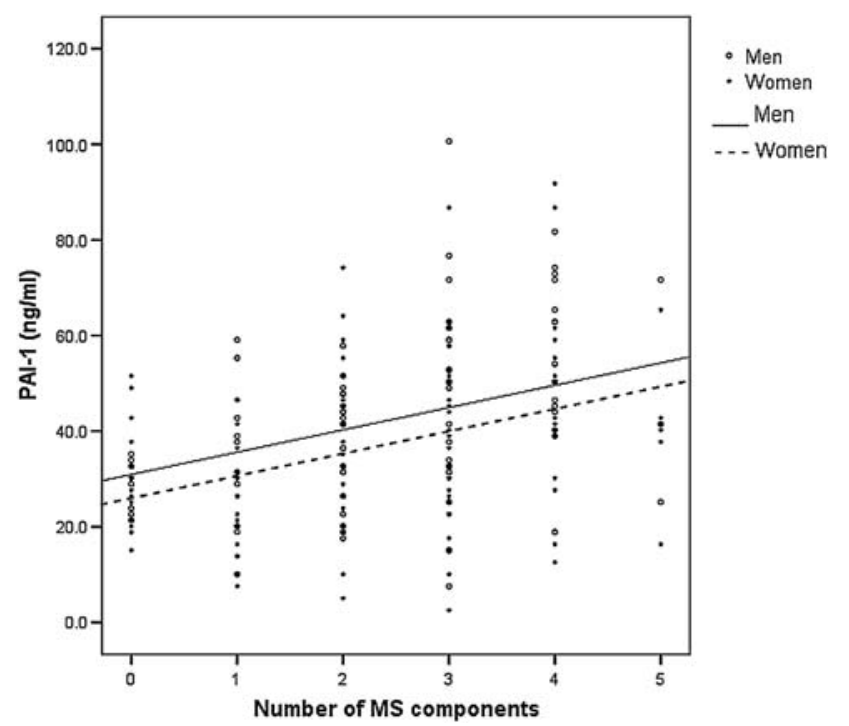

Figure 2. Relationship between PAI-1 concentrations and the number of metabolic syndrome (MS) criteria met $(n=186)$.

Plasma concentrations of PAI-1 were significantly higher in subjects with MS in comparison to the non-MS subjects (men $49.2 \pm 19.8$ vs. $35.0 \pm 12.2 \mathrm{ng} / \mathrm{ml}$ and women $42.0 \pm 19.7 \mathrm{vs}$. $31.6+14.6 \mathrm{ng} / \mathrm{ml} ; \mathrm{p}<0.0001$ ) (Fig. 1). Significant differences in the plasma concentrations of PAI-1 were found according to gender $(\mathrm{p}<0.037)$. PAI-1 levels were associated with diastolic blood pressure $(\mathrm{p}=0.028)$, triglyceride $(\mathrm{p}=0.03)$ and waist circumference $(\mathrm{p}=0.01)$ (controlled by age and gender). Plasma levels of PAI-1 concentration were linearly related to the number of MS criteria, with a different intercept by gender ( $\mathrm{p}<0.001)$ (Fig. 2). Each additional MS component increased PAI-1 concentrations by $4.7(2.9-6.4) \mathrm{ng} / \mathrm{ml}$.

Plasma concentrations of fibrinogen were significantly higher in subjects with MS $(274.0 \pm 82.1 \mathrm{mg} / \mathrm{dl})$ than in the non-MS group $(232.7 \pm 66.6 \mathrm{mg} / \mathrm{dl})(\mathrm{p}=0.0002)($ Fig. 3). There

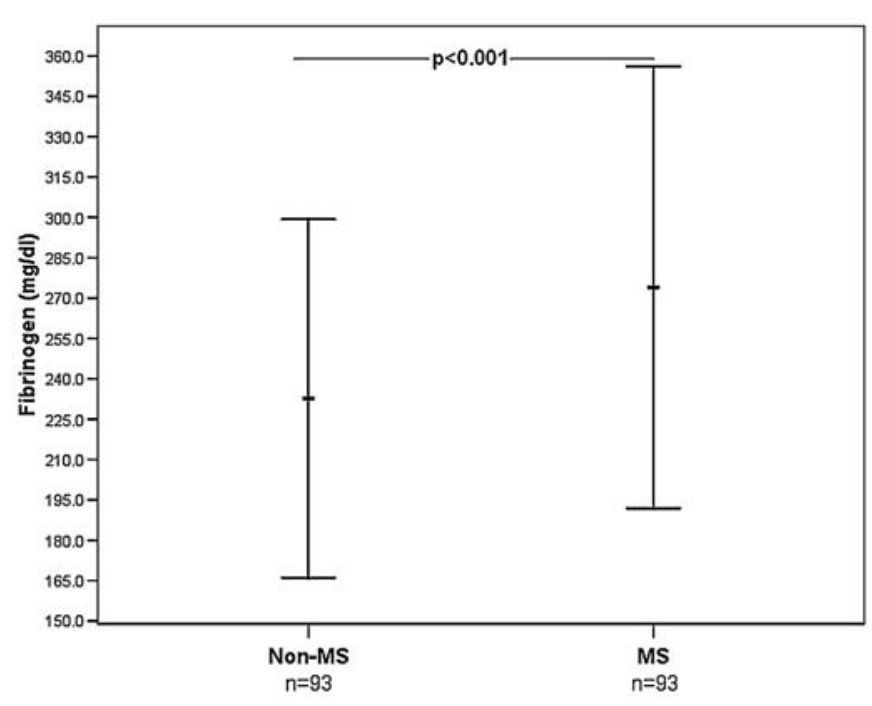

Figure 3. Mean and standard deviations for plasma concentrations of fibrinogen in the metabolic syndrome (MS) and control (non-MS) groups.

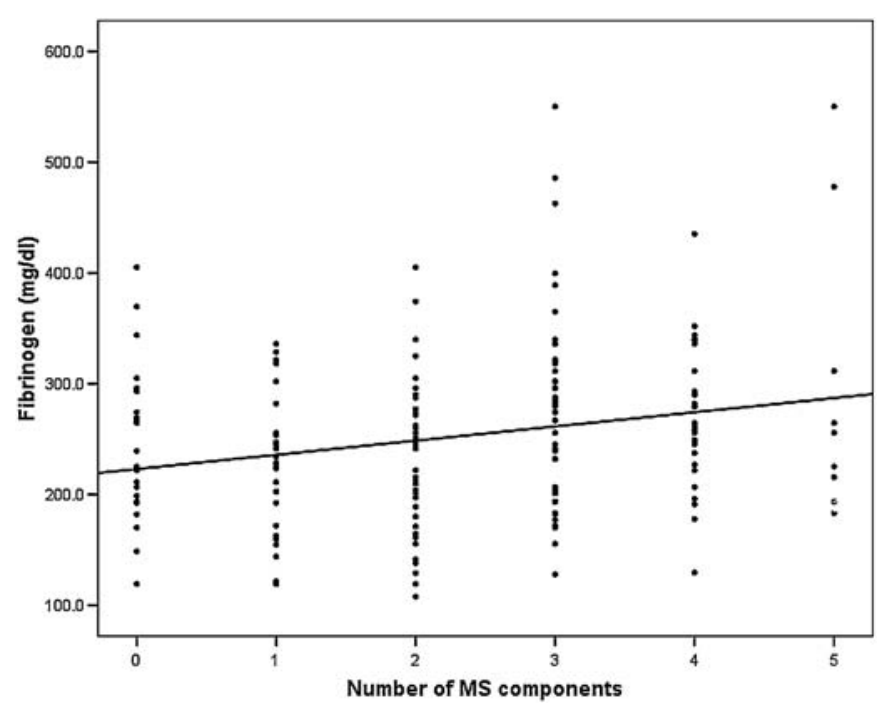

Figure 4. Relationship between fibrinogen concentrations and the number of metabolic syndrome (MS) criteria met $(n=186)$.

were no differences associated with gender or age in the plasma concentrations of fibrinogen, which were only associated with HDL-c $(\mathrm{p}=0.02)$ (controlled by age and gender). Fibrinogen concentration was linearly related to the number of MS components, without gender-related differences $(\mathrm{p}<0.001)$ (Fig. 4). Each additional MS component increased the fibrinogen level by $12.8(4.9-20.7) \mathrm{mg} / \mathrm{dl}$.

\section{Discussion}

Cardiovascular disease is a major cause of mortality worldwide (22). Evidence suggests that metabolic syndrome is associated with CVD $(23,24)$. PAI-1 and fibrinogen, as nontraditional risk factors of CVD, have been associated with an elevated risk of CVD in the general population (25).

Abnormalities in hemostasis represent a well-known link between MS and thrombosis. Patients with MS have higher plasma concentrations of pro-thrombotic factors (fibrinogen, 
von Willebrand factor) as compared to controls (26). Similarly, plasma concentrations of PAI-1 have been shown to be higher in obese patients than in non-obese controls (27). It has been proposed that the secretion of IL- 6 by adipose tissue, combined with the actions of adipose tissue-expressed TNF- $\alpha$ in obesity, may underlie the association of insulin resistance with endothelial dysfunction, coagulopathy and coronary heart disease (28). Another possibility is that various hormonal abnormalities (androgen, catecholamines) associated with the accumulation of body fat may contribute to the impairment of the coagulative pathway in obesity (28).

Concerning plasminogen activator inhibitor-1, we found elevated plasma levels of PAI-1 in the MS group (men and women) compared with the non-MS group. MS subjects in our study presented similar plasma levels of PAI-1 to those found in other studies: $42-50 \mathrm{ng} / \mathrm{ml}$ in subjects 30-75 years of age with MS (29-31). On the other hand, similar to our study, Pankow et al (32) found elevated levels of PAI-1 in men $(33.2 \pm 38.9 \mathrm{ng} / \mathrm{ml})$ compared to women $(24.2 \pm 34.8 \mathrm{ng} / \mathrm{ml})$ with MS, 40-69 years of age.

We found significant linear associations between PAI-1 and diastolic blood pressure, triglycerides, waist circumference and the number of MS criteria. Other studies found statistically significant correlations between PAI-1 and triglycerides (33), waist circumference (34), HDL-c $(33,34)$, BMI $(35)$ and the number of MS criteria met.

Studies have concluded that the most important factor for increased plasma levels of PAI-1 is obesity, but additional variables explaining these levels may exist $(31,36,37)$. In this context, Pankow et al (32) proposed the existence of polymorphisms which regulate PAI-1 levels.

High levels of PAI-1 in subjects with MS may be explained by elevated proinflammatory cytokines, such as tumor necrosis factor (38), dyslipidemia (39) platelet hyperactivity (40) and elevated insulin levels (41), as these induce PAI-1 secretion from the endothelium, liver and adipose tissue. Additional studies are needed to identify the genetic factors, environmental factors, and gene environment interactions regulating PAI- 1 concentrations.

Concerning fibrinogen, we found that fibrinogen plasmatic levels were significantly elevated in MS subjects with respect to the non-MS group. Other studies found, in individuals of a similar age, values slightly higher than ours, with a mean of approximately $305 \mathrm{mg} / \mathrm{dl}$ in an MS group $(31,35,42,43)$.

We found a correlation between plasma levels of fibrinogen and HDL-c and the number of MS criteria met. Other researchers found correlations with HDL-c (34), total cholesterol (44), BMI, systolic and diastolic pressure, HDL-c and triglycerides (43), and the number of diagnostic criteria of MS met (31). Mertens et al (36) found no significant differences between subjects with and without MS.

It is possible that the increase in fibrinogen (by favoring coagulation) and PAI-1 (by inhibiting the fibrynolitic system) in MS subjects favors the development of thrombotic arterial events.

\section{Acknowledgements}

This study was supported by the Research Program of Cardiovascular Disease Risk Factors (PIFRECV), Universidad de Talca, Chile.

\section{References}

1. Alexander CM, Landsman PB, Teutsch SM and Haffner SM: NCEP-defined metabolic syndrome, diabetes, and prevalence of coronary heart disease among NHANES III participants age 50 years and older. Diabetes 52: 1210-1214, 2003.

2. Reaven GM: Insulin resistance, cardiovascular disease, and the metabolic syndrome: how well do the emperor's clothes fit? Diabetes Care 27: 1011-1012, 2004.

3. Abdul-Ghani MA, Tripathy D and DeFronzo RA: Contributions of beta-cell dysfunction and insulin resistance to the pathogenesis of impaired glucose tolerance and impaired fasting glucose. Diabetes Care 29: 1130-1139, 2006.

4. Executive Summary of The Third Report of The National Cholesterol Education Program (NCEP) Expert Panel on Detection, Evaluation, and Treatment of High Blood Cholesterol In Adults (Adult Treatment Panel III). JAMA 285: 2486-2497, 2001.

5. Ford ES, Giles WH and Dietz WH: Prevalence of the metabolic syndrome among US adults: findings from The Third National Health and Nutrition Examination Survey. JAMA 287: 356-359, 2002.

6. MINSAL: Ministerio de Salud de Chile. Encuesta Nacional de Salud 2003. Departamento de Salud Pública de la Pontificia Universidad Católica de Chile. Informe Técnico, 2003.

7. Mujica V, Leiva E, Icaza G, et al: Evaluation of metabolic syndrome in adults of Talca city, Chile. Nutr J 7: 14, 2008.

8. Trayhurn P and Beattie JH: Physiological role of adipose tissue: white adipose tissue as an endocrine and secretory organ. Proc Nutr Soc 60: 329-339, 2001.

9. Beltowski J: Adiponectin and resistin - new hormones of white adipose tissue. Med Sci Monit 9: RA55-RA61, 2003.

10. Ferroni P, Basili S, Falco A and Davi G: Inflammation, insulin resistance, and obesity. Curr Atheroscler Rep 6: 424-431, 2004.

11. Reaven GM: Banting lecture 1988. Role of insulin resistance in human disease. Diabetes 37: 1595-1607, 1988.

12. Liese AD, Mayer-Davis EJ and Haffner SM: Development of the multiple metabolic syndrome: an epidemiologic perspective. Epidemiol Rev 20: 157-172, 1998.

13. Meigs JB, Mittleman MA, Nathan DM, et al: Hyperinsulinemia, hyperglycemia, and impaired hemostasis: the Framingham Offspring Study. JAMA 283: 221-228, 2000.

14. Kannel WB: Metabolic risk factors for coronary heart disease in women: perspective from the Framingham Study. Am Heart J 114: 413-419, 1987.

15. Juhan-Vague I, Alessi MC and Vague P: Increased plasma plasminogen activator inhibitor 1 levels. A possible link between insulin resistance and atherothrombosis. Diabetologia 34: 457-462, 1991.

16. Hamsten A: Hemostatic function and coronary artery disease. $\mathrm{N}$ Engl J Med 332: 677-678, 1995.

17. Hamsten A, De Faire U, Walldius G, et al: Plasminogen activator inhibitor in plasma: risk factor for recurrent myocardial infarction. Lancet 2: 3-9, 1987.

18. Palomo GI, Icaza NG, Mujica EV, et al: Prevalence of cardiovascular risk factors in adults from Talca, Chile. Rev Med Chil 135: 904-912, 2007.

19. Nathan DM, Davidson MB, DeFronzo RA, et al: Impaired fasting glucose and impaired glucose tolerance: implications for care. Diabetes Care 30: 753-759, 2007.

20. Ministerio de Salud, Programa de Salud del Adulto. Manual: 'Exámen de salud preventivo del adulto'. Norma General Técnica No9. MINSAL, 1995.

21. Habitch J: Estandarización de métodos epidemiológicos cuantitativos sobre el terreno. Bol of Sanit Panam 76: 375-384, 1974.

22. WHO: World Health Organization. Informe sobre la salud en el mundo. Technical Report Series ISBN 924356207 X. Geneva, 2002.

23. Lorenzo C, Williams K, Hunt KJ and Haffner SM: Trend in the prevalence of the metabolic syndrome and its impact on cardiovascular disease incidence: the San Antonio Heart Study. Diabetes Care 29: 625-630, 2006.

24. Hanley AJ, Williams K, Stern MP and Haffner SM: Homeostasis model assessment of insulin resistance in relation to the incidence of cardiovascular disease: the San Antonio Heart Study. Diabetes Care 25: 1177-1184, 2002.

25. Ridker PM: Inflammation, infection, and cardiovascular risk: how good is the clinical evidence? Circulation 97: 1671-1674, 1998.

26. Eckel RH: Mechanisms of the components of the metabolic syndrome that predispose to diabetes and atherosclerotic CVD. Proc Nutr Soc 66: 82-95, 2007. 
27. Darvall KA, Sam RC, Silverman SH, Bradbury AW and Adam DJ: Obesity and thrombosis. Eur J Vasc Endovasc Surg 33: 223-233, 2007.

28. Cho LW, Randeva HS and Atkin SL: Cardiometabolic aspects of polycystic ovarian syndrome. Vasc Health Risk Manag 3: 55-63, 2007.

29. Hamdy O, Ledbury S, Mullooly C, et al: Lifestyle modification improves endothelial function in obese subjects with the insulin resistance syndrome. Diabetes Care 26: 2119-2125, 2003.

30. Aso Y, Wakabayashi S, Yamamoto R, Matsutomo R, Takebayashi $\mathrm{K}$ and Inukai T: Metabolic syndrome accompanied by hypercholesterolemia is strongly associated with proinflammatory state and impairment of fibrinolysis in patients with type 2 diabetes: synergistic effects of plasminogen activator inhibitor-1 and thrombin-activatable fibrinolysis inhibitor. Diabetes Care 28: 2211-2216, 2005.

31. Kahn SE, Zinman B, Haffner SM, et al: Obesity is a major determinant of the association of C-reactive protein levels and the metabolic syndrome in type 2 diabetes. Diabetes 55: 2357-2364 2006.

32. Pankow JS, Folsom AR, Province MA, et al: Segregation analysis of plasminogen activator inhibitor-1 and fibrinogen levels in the NHLBI family heart study. Arterioscler Thromb Vasc Biol 18: 1559-1567, 1998.

33. Bahia L, Aguiar LG, Villela N, et al: Relationship between adipokines, inflammation, and vascular reactivity in lean controls and obese subjects with metabolic syndrome. Clinics 61: 433-440, 2006.

34. Sakkinen PA, Wahl P, Cushman M, Lewis MR and Tracy RP: Clustering of procoagulation, inflammation, and fibrinolysis variables with metabolic factors in insulin resistance syndrome. Am J Epidemiol 152: 897-907, 2000.
35. Godsland IF, Crook D, Proudler AJ and Stevenson JC: Hemostatic risk factors and insulin sensitivity, regional body fat distribution, and the metabolic syndrome. J Clin Endocrinol Metab 90: 190-197, 2005.

36. Mertens I, Verrijken A, Michiels JJ, van der Planken M, Ruige JB and van Gaal LF: Among inflammation and coagulation markers, PAI-1 is a true component of the metabolic syndrome. Int J Obes 30: 1308-1314, 2006

37. Kozek E, Katra B, Malecki M and Sieradzki J: Visceral obesity and hemostatic profile in patients with type 2 diabetes: the effect of gender and metabolic compensation. Rev Diabet Stud 1: 122-128, 2004.

38. Yudkin JS: Inflammation, obesity, and the metabolic syndrome. Horm Metab Res 39: 707-709, 2007.

39. Suzuki T and Homma S: Treatment of hypertension and other cardiovascular risk factors in patients with metabolic syndrome. Med Clin North Am 91: 1211-1223, 2007.

40. Kestin AS, Ellis PA, Barnard MR, Errichetti A, Rosner BA and Michelson AD: Effect of strenuous exercise on platelet activation state and reactivity. Circulation 88: 1502-1511, 1993.

41. Potter van Loon BJ, Kluft C, Radder JK, Blankenstein MA and Meinders AE: The cardiovascular risk factor plasminogen activator inhibitor type 1 is related to insulin resistance. Metabolism 42: 945-949, 1993.

42. Kurl S, Laukkanen JA, Niskanen L, et al: Metabolic syndrome and the risk of stroke in middle-aged men. Stroke 37: 806-811, 2006.

43. Imperatore G, Riccardi G, Iovine C, Rivellese AA and Vaccaro O: Plasma fibrinogen: a new factor of the metabolic syndrome. A population-based study. Diabetes Care 21: 649-654, 1998.

44. Lepira FB, M'Buyamba-Kabangu JR, Kayembe KP and Nseka MN: Correlates of serum lipids and lipoproteins in Congolese patients with arterial hypertension. Cardiovasc J S Afr 16: 249-255, 2005. 